\title{
The Analytical Value of the Adversarial- Inquisitorial Dichotomy in Approaches to Proof: The Examples of England and Turkey
}

\author{
Itham-Tahkik (Adversarial-Inquisitorial) Dikotomosinin İspat \\ Hususunda Analitik Değeri: Türkiye ve Ingiltere Örnekleri
}

\section{Halil CESUR ${ }^{1 \oplus}$}

${ }^{1}$ LLM (University of Nottingham School of Law)

\begin{abstract}
Common law systems differ substantially from civil law jurisdictions as to how and by whom the investigation and trial are to be conducted, and how rules of evidence are to be constructed. Whilst common law systems are considered to follow an adversarial trial process model, civil law traditions have generally been associated with an inquisitorial procedure. Yet, convergence between the criminal justice systems of the common law and those of the civil law in relation to proof and evidence suggest that the labels "adversarial" and "inquisitorial" cannot be used today to show the general character and structure of criminal trial models. Rather, they can only be used to help us begin to understand the different features that traditionally exist in different systems, or at best they can be used today to grasp the effects of the tradition on the mentality of parties during the trial. The aim of this article is first to set a basis for understanding the adversarial/inquisitorial dichotomy by looking at distinctive elements of each legal system, and then, so as to evaluate whether this conceptual dichotomy is useful, it aims to elaborate further the purposes of English and Turkish criminal trials and examine the evidentiary rules of the two jurisdictions.
\end{abstract}

Keywords: Adversarial trial process, inquisitorial procedure, rules of evidence

\section{öz}

Müşterek hukuk sistemleri Kıta Avrupası hukuk sistemlerinden soruşturmanın ve yargılamanın nasıl ve kim tarafından yürütülmesi konusunda ve delillere ilişkin kurallar bakımından temel bir şekilde farklılık gösterir. Müşterek hukuk sistemlerinde itham usulü (adversarial) ceza yargısının esasını oluştururken Kıta Avrupası́nda tahkik (inquisitorial) sistemi benimsenmiştir. Ancak bu iki hukuk geleneğinin ispat ve delil hukuklarındaki yakınlaşma bugün için 'adversarialinquisitorial' kavramsallaştırmasının ceza yargılaması modellerini açıklamak için kullanılamayacağını gösteriyor. Mezkur iki kavram yalnızca hukuk sistemlerinin geleneksel olarak farklılık gösteren özelliklerini izah edebilir. En iyi ihtimalle, muhkem hukuk geleneklerinin yargılamanın süjeleri üzerindeki etkisini anlamaya yardımcı olabilir. Bu makalenin amacı iki farklı hukuk sisteminde var olan o ülkeye münhasır unsurlara bakarak'adversarial-inquisitorial' dikotomisini kavramak için bir temel oluşturmak ve bu doğrultuda İngiliz ve Türk ceza yargılamalarının delile ilişkin kurallarını incelemektir.

Anahtar Kelimeler: Itham yargı usulü, tahkik sistemi, delil hukuku 


\section{Introduction}

It has long been recognised that common law systems differ substantially from civil law jurisdictions as to how and by whom the investigation and trial are to be conducted, and how the rules of evidence are to be constructed. Whilst common law systems are considered to have had a model of adversarial trial process, civil law traditions have generally been associated with an inquisitorial procedure. ${ }^{1}$ Though, for some, the accusatorial/inquisitorial dichotomy is still central to comparative legal analysis, ${ }^{2}$ the distinction between the two models is not predicated upon a sound footing - not least because there is no clear consensus on the meaning of the concepts ${ }^{3}$ - but also it is viewed as 'an unsatisfactory conceptual prism through which to scrutinise modern legal process in comparative perspective' ${ }^{4}$ In analysing and testing the adversarial and inquisitorial taxonomies, perhaps one of the most acute differences between the criminal justice systems of the common law and those of the civil law lies, to a large extent, in their approach to proof and evidence. In this sense, one can claim that rules vary considerably between the systems in terms of the gathering, presentation and challenging of evidence with diverse procedural arrangements dealing with admissible and inadmissible evidence in criminal proceedings. ${ }^{5}$

The aim of this article is first to set a basis for understanding the adversarial/ inquisitorial dichotomy by looking at distinctive elements of each legal system, then so as to evaluate whether this conceptual dichotomy is useful, it will expound the purposes of the English and Turkish criminal trials and examine the evidentiary rules of the two jurisdictions.

\section{The Adversarial and Inquisitorial Dichotomy}

Before concentrating on the differences between the English common law and the Turkish legal system, it would be appropriate to briefly set out the core features of the

1 Andrea Ryan, Towards a System of European Criminal Justice the Problem of Admissibility of Evidence (Oxon; Routledge, 2014) 1.

2 Máximo Langer, 'Models of the Criminal Process' in Markus D Dubber, Tatjana Hörnle(Eds.) The Oxford Handbook of Criminal Law (OUP 2014) 892; see also D. Sklansky, 'Anti-Inquisitorialism' (2009) in Harv. L. Rev. (2009) 122/6 1634, 1704.

3 John Jackson, 'Taking Comparative Evidence Seriously' in P. Roberts and M. Redmayne (Eds.), Innovations in Evidence and Proof: Integrating Theory, Research and Teaching (Hart 2007) 291.

4 Paul Roberts, 'Faces of justice adrift? Dama's Comparative Method and the Future of Common Law Evidence' in: J. Jackson, M. Langer, P. Tillers (Eds.) Crime, Procedure and Evidence in a Comparative and International Context: Essays in Honour of Professor Mirjan Damaska (Hart 2008) 295.

5 Andrea Ryan, Towards a System of European Criminal Justice the Problem of Admissibility of Evidence (Oxon; Routledge 2014) 3. 
legal traditions that are rooted in the two jurisdictions. The Turkish criminal process is supposed to fall within the inquisitorial legal tradition, while the English criminal trial is often described as adversarial in nature.

In juxtaposing the adversary/accusatorial ${ }^{6}$ system of criminal trials with the inquisitorial system, it is essential to analyse the way proceedings are structured. Whereas adversariness can be regarded as a process in which 'a dispute between two sides in a position of theoretical equality before a court which must decide the outcome of the contest' is resolved, the legal process is conceived as an 'official and thorough inquiry' in an inquest model in which the prosecutor generally controls the pre-trial stage, and is viewed as a neutral representative of the state rather than an opponent of the suspect. ${ }^{7}$ In other words, it is the state, under the inquisitorial system, rather than the private accuser, who is responsible for assembling the case against the accused, and the onus are upon members of the judiciary who are holding the powers of deciding on the course of investigation and examining the witnesses at trial. ${ }^{8}$ In an ideal adversarial system, the judge is considered to be a passive arbitrator or mere umpire with little direct interference in the fact-finding process, but (s)he plays a crucial role at trial by restricting the information presented to the jury. ${ }^{9}$ The corollary of this in the adversary model is that the contestants or competitors are able to draw the contours of the dispute and have responsibility for selecting, presenting, testing, and evaluating the evidence pertinent to the case. ${ }^{10}$ Thus, it is thought in the party-driven process that the disputants must be relatively equal in terms of sources (equality of arms) in the "contest" to ensure that the trial is fairly conducted while determining who is the "winner". "This seems also a reflection of the idea that adversarialism "is based on the premise that all people, including persons accused of criminal offences, enjoy rights

6 Although legal commentators sometimes employ the concepts of "accusatorial' and "adversarial" interchangeably, these concepts are not necessarily same. Whereas 'adversarial' denotes a means of a dispute resolution, 'accusatorial' can be seen as a 'classic procedural model', one that 'assigns great social value to keeping the state out of disputes' and one that grants the accused a presumption of innocence until the accuser has sufficient evidence for the conviction of the accused. That being the case, for the purpose of this article, the two terms have been used interchangeably. See A. Goldstein, 'Reflections on Two Models: Inquisitorial Themes in American Criminal Procedure' in Stan. L. Rev. (1973-74) 26/5 1009, 1017; J. Jackson, S. Doran, Judge without Jury: Diplock Trials in the Adversary System (Clarendon 1995) 57.

7 Mirjan Damaška, "Evidentiary "Barriers" to Conviction and Two Models of Criminal Procedure: A Comparative Study' in U. Pa. L. Rev. (1973) 121 506, 563-564.

8 Matthew King, 'Security, Scale, Form and Function: The Search for Truth and the Exclusion of Evidence in Adversarial and Inquisitorial Justice Systems' in Int'l Legal Persp. (2001-2) 12 185, 194ff.

9 Mirjan Damaška, Evidence Law Adrift (Yale University Press 1997) 72.

10 John Jackson, S. Doran, Judge without Jury: Diplock Trials in the Adversary System (Clarendon 1995) 67

11 Ibid, 66. 
and the freedom to express their legitimate independent perspectives'. ${ }^{12}$ On the other hand, in the purest form of the inquest model, there is no "adversary" to dominate; rather, there are protagonists who are anticipated to contribute to the inquiry whose overriding goal is to discover the truth of the allegation. ${ }^{13}$ Besides, it has commonly been stated that inquisitorial trials are described as secret, and hinge heavily on written materials contained in a single investigative dossier which is to be passed to the trial judge for the determination of the guilt and innocence of the accused. ${ }^{14}$ Conversely, adversarial proceedings refer to a public procedure where evidence is presented orally and subject to a process of examination and cross-examination during the trial that includes a jury deciding the facts of the case. ${ }^{15}$ In sum, according to the model of adversarial/inquisitorial dichotomy, an adversarial trial system can be distinguished from the inquisitorial procedure with regard to the primary aim of the process, the role of the participants and the main features of the proceedings.

In examining different legal systems, though seemingly sufficiently promising, the analytical labels in question may not describe precisely either system in part because the question what elements are essential to the adversarial and inquisitorial models has not been lucidly answered, and hence 'locating particular systems along the spectrum of procedural types will always be controversial' ${ }^{16}$ Moreover, given the impact of the European Court of Human Rights(ECHR) on domestic legal systems including England and Turkey, it may be more accurate to say that 'a new model of proof that is better characterised as 'participatory' than as 'adversarial' or "inquisitorial" has been devised as a common set of evidentiary principles. ${ }^{17}$ The adversarial/inquisitorial polarity was also criticised by Damaska, as 'cumbersome',

12 Richard Vogler, A World View of Criminal Justice (Aldershot: Ashgate 2005) 129.

13 Andrea Ryan, Towards a System of European Criminal Justice the Problem of Admissibility of Evidence (Oxon; Routledge 2014) 72.

14 Mireille Delmas-Marty; John R. Spencer LLB (Eds.) European Criminal Procedures (CUP 2002) 21.

15 Abraham Goldstein, 'Reflections on Two Models: Inquisitorial Themes in American Criminal Procedure' in Stan. L. Rev. (1973-74) 26/5 1009, 1017 It is worth noting that, for Damaska, jury trial and the principle of orality are not essential to an adversary model, but 'the ideological underpinning of adversarial process, stemming from Lockean liberal values of distrust of the state and freedom from restraint, may make these features a matter of choice'. See M. Damaška, 'Evidentiary "Barriers" to Conviction and Two Models of Criminal Procedure: A Comparative Study’ in U. Pa. L. Rev. (1973) 121 506, 565; Andrea Ryan, Towards a System of European Criminal Justice the Problem of Admissibility of Evidence (Oxon; Routledge 2014) 71.

16 John Jackson, 'Taking Comparative Evidence Seriously', in P. Roberts and M. Redmayne(Eds.), Innovations in Evidence and Proof: Integrating Theory, Research and Teaching (Hart 2007) 291.

17 John Jackson, 'The Effect of Human Rights on Criminal Evidentiary Processes: Towards Convergence, Divergence or Realignment?' (2005) 68 (5) in Modern Law Review (2005) 68/5 737, 737. 
'difficult to employ as an instrument of analysis', ${ }^{18}$ and 'unsupported by evidence and allowing unwarranted priority to the trial stage'. ${ }^{19}$ Instead of a somewhat outmoded approach, he has created an alternative analytical framework to account for variations between legal systems with the terms 'hierarchical' and 'coordinate' by which the arrangement of the judicial authority has been centralised. ${ }^{20}$ Nevertheless, either historically based on the adversarial/inquisitorial dichotomy or in the words of Damaska "predominantly analytical and interpretative" models (the hierarchical and coordinate), ${ }^{21}$ provide us only with 'ideal types which do not necessarily reflect current procedures in either continental Europe or the Anglo-American jurisdictions' ${ }^{22}$

\section{The Aim of the Trial}

To elucidate differences between the common law and civil law jurisdictions as to how rules, principles and doctrines that govern the admission, examination and evaluation of evidence, and to analyse the labels 'adversarial' and 'inquisitorial', this section will scrutinise how the law of evidence operates in the English and Turkish criminal proceedings.

As a characteristic of the common law system, the English legal system has adopted a distinct 'law of evidence' as a separate discipline developed in the nineteenth century through jurists who isolated evidentiary rules from the study of criminal process and substantive law. ${ }^{23}$ This appears to be emanating mainly from the belief that a bilateral contest model should be designed in such a way that grants the parties remarkable latitude in how to construct and present their case, and the manner in which they question witnesses at trial. ${ }^{24}$ It follows that evidence gathered and presented by each party who is to pursue victory with near-complete autonomy, should be subject to some legal controls before the tribunal of fact. In this regard, in view of the tightly regulated rules of evidence, it can be said that the English criminal trial has more

18 Mirjan Damaska, The Faces of Justice and State Authority: A Comparative Approach to the Legal Process (Yale University Press 1986) 5.

19 Richard Vogler, A World View of Criminal Justice (Aldershot: Ashgate 2005) 8.

20 Mirjan Damaska, 'Structures of Authority and Comparative Criminal Procedure' in Yale Law Journal (1974-75) 84 480, 543 The framework set out by Damaska is somewhat convincing from many perspectives; yet, it goes beyond the confines of this article.

21 Mirjan Damaska, Evidence Law Adrift (New Haven: Yale University Press, 1997) 3.

22 Andrea Ryan, Towards a System of European Criminal Justice the Problem of Admissibility of Evidence (Oxon; Routledge 2014) 80.

23 John R. Spencer, 'Adversarial vs inquisitorial systems: is there still such a difference?' in the International Journal of Human Rights (2016) 20/5 601, 605.

24 Claire McGourlay, Doak Jonathan, Evidence in Context (4th edn, Oxon: Routledge 2015) 125. 
evidentiary barriers than its Turkish counterpart. However, it should also be underlined that with the Criminal Justice Act 2003 and the Criminal Procedure Rules 2005 there has been 'a shift away from a rigid regime of exclusionary evidential rules towards a broader freedom of proof'. ${ }^{25}$ Moreover, with the Criminal Procedure Rules, the intention was to promote a culture change in criminal case management by giving 'courts explicit powers and responsibilities to manage cases actively' ${ }^{26}$ Therefore, the firm commitment to principles of party autonomy and judicial passivity in the English criminal justice system seems to have faded regarding the emphasis on active case management, which marks an important inroad into the adversarial tradition. ${ }^{27}$ It was also argued that such a strong judicial insistence results in a situation where the English criminal trial on the adversarial/inquisitorial spectrum no longer lies somewhere it can be regarded as a game in which the participants are expected to enter the ring. ${ }^{28}$

In contradiction to the English counterpart, the Turkish legal system does not recognise evidence as a distinct branch of the law, and most regulations relating to evidence and proof are contained within the code of criminal procedure. ${ }^{29}$ Since the collection of evidence is conducted and supervised by an impartial public prosecutor rather than parties, the selective filtering of information has been relatively avoided. The lack of lay involvement can also be seen as another reason for few evidentiary barriers in Turkey where the trial judge, as the trier of fact as well as the trier of law, is deemed competent enough to exercise due diligence when assessing evidence before determining guilt. ${ }^{30}$ Yet, the fact that there is absolute inhibition of evaluation of the unlawful evidence rendered by either public authorities or private persons, which is a constitutional protection, ${ }^{31}$ places focus more on the importance of due process protections for defendants. More will be said below, but it should be stated at this juncture that the restrictive evidentiary rules might in themselves be a strong indication that the Turkish criminal justice system leans towards an adversarial direction.

In accordance with the inquest model, the principle of 'free proof' or 'free

\section{Ibid 16.}

Treasury Minutes on the Fifteenth, Twentieth to Twenty-second and Twenty-fourth Reports from the Committee of Public Accounts 2004-2005, CM6667, [23].

Ian Dennis, The Law of Evidence (6th edn, Sweet \& Maxwell 2017) 24.

Ibid, 25.

Yener Ünver, Hakan Hakeri, Ceza Muhakemesi Hukuku (Ankara: Adalet Yayınları 2012) 669.

Ceza Muhakemesi Kanunu, Art. 230.

Constitution of the Republic of Turkey 1982, s.38: "Findings obtained through illegal methods shall not be considered evidence.". 
evaluation of evidence' has been embraced in Turkey, which dictates that any form of relevant evidence can be used by the judge in reaching a verdict. ${ }^{32}$ Free evaluation of evidence at trial, however, comprises some adversarial elements, inter alia, that require evidence to be heard and challenged by the parties orally at trial under Article 216 of the Turkish Criminal Procedure Act. ${ }^{33}$ A system of free proof might be explained by the fact that the highest value in the criminal process, as clearly provided in the Turkish Criminal Code, is to reveal the material truth ${ }^{34}$ with 'a judicial quasiscientific search'. ${ }^{35}$ This is distinct from the principle which has recently been adopted in England where the Criminal Procedure Rules made it clear that 'the overriding objective of [the] procedural code is that criminal cases be dealt with justly, ${ }^{36}$ despite that the priority given to a particular value or principle is somewhat alien to the common law tradition. ${ }^{37}$ The English criminal trial is also supposed to discover the truth provided that 'the contest is fair and the parties are given an equal opportunity to put their case' ${ }^{38}$ However, it was held that truth should not be the primary goal:
[A] preoccupation with material truth may be not only futile but dangerous to society as well. If the objective of the judicial process were the disclosure of facts, then any technique that increases the prospect of gathering fact would be permissible. ${ }^{39}$

That being the case, the evidential constraint in the English trial which prevents the judge from undertaking a search for relevant evidence is said to be an obstacle to the ability of the trial to uncover truth. ${ }^{40}$ It can also be observed that in practice certain aspects of evidence are selectively filtered by the police or the Crown Prosecution Service (CPS) in order to persuade the decision-maker 'that their presentation of events

32 Özgün Öztunç, 'Ceza Muhakemesinde Hukuka Aykiri Deliller' (PhD Thesis, Marmara Üniversitesi 2010) 25.

33 Ceza Muhakemesi Kanunu, Art. 217: "The judge must only rely upon evidence that is presented at the main hearing and has been discussed in his presence while forming his judgment.".

34 Ceza Muhakemesi Kanunu, Art. 216.

35 Vahit Bıçak, 'A Comparative Study of the Problem of the Admissibility of Improperly Obtained Evidence' (PhD Thesis, University of Nottingham 1995) 42.

36 The Criminal Procedure Rules, The Criminal Practice Directions October 2015 edition, S. 1.1.

37 Claire McGourlay, Doak Jonathan, Evidence in Context (Oxon: Routledge, 4th Ed. 2015) 16.

38 John Jackson, Sean Soran, 'Two Models of Proof' in Judge without Jury: Diplock Trials in the Adversary System (Clarendon 1995) 66.

39 Stephan Landsman, The Adversary System, a Description and Defence (Washington: The American Enterprise Institute 1984) 37.

40 Claire McGourlay, Doak Jonathan, Evidence in Context (4th edn, Oxon: Routledge 2015) 35. 
represents a historically correct narrative'. Thus, the English trial might be seen in this regard as 'a poor vehicle for delivering justice that is ultimately based on the truth'. ${ }^{41}$

\section{Rules of Disclosure}

As the purpose of the Turkish trial is to seek the truth of what happened, parties have a duty to uncover any available information that is requested of them and access to the case file (dossier) in the investigation stage. ${ }^{42}$ Nevertheless, the power to review and examine the contents of the dossier related to the investigation phase given to the defence counsel is not free from limitations; it may be restricted (upon request of the public prosecutor and by decision of the Justice of the Peace), if a review into the contents of the file, or copies taken, impedes the goal of the ongoing investigation. ${ }^{43}$ However, the statements provided by the suspect, the written expert opinions and the records of other judicial proceedings during which the suspect is entitled to be present cannot be subject to restriction to access. ${ }^{44}$ The major consideration in relation to the limitation of access to the dossier is the secrecy and efficiency of the investigation that is of particular importance to truth-finding; however, it is argued that considerations of secrecy should not override the procedural rights of the accused. ${ }^{45}$ The Turkish Constitutional Court and the ECtHR also stress the importance of the balance that needs to be struck between the right to have a fair trial and the secrecy and efficiency of the investigation. In the words of the ECtHR:

The Court acknowledges the need for criminal investigations to be conducted efficiently, which may imply that part of the information collected during them is to be kept secret in order to prevent suspects from tampering with evidence and undermining the course of justice. However, this legitimate goal cannot be pursued at the expense of substantial restrictions on the rights of the defence. Therefore, information which is essential for the assessment of the lawfulness of a detention should be made available in an appropriate manner to the suspect's lawyer. ${ }^{46}$

41 Ibid, 36.

42 Ceza Muhakemesi Kanunu, Art.153/1.

43 Ibid, Art.153/2.

44 Ibid, Art.153/2.

45 Güneş Okuyucu-Ergün, 'Soruşturmanin Gizliliği' in AUHFD, (2010) 59(2) 243, 260.

46 Case of Garcia Alva V. Germany [2001] Lietzow v. Germany, Application no. 23541/94 [42] (Lietzow v. Germany); See also: Yargitay (High Court of Appeals) Case 2014/195, N.D 2015/116, D. D 23.12.2015, [63]. 
It should also be noted that evidence not disclosed in the dossier at pre-trial stage must be available to the defence at the beginning of the trial stage to ensure that the defendant is aware of the evidence against him. Thus, it should be emphasised that non-disclosure of evidence cannot be justified on the grounds of public interest or the sensitive nature of material that is to be presented.

As for pre-trial disclosure in England, there is a basic requirement or the "golden rule" on the part of the prosecution that it "disclose[s] to the accused any prosecution material which has not been disclosed to the accused and which might reasonably be considered capable of undermining the case for the prosecution against the accused or of assisting the case for the accused ${ }^{\prime 4}$ The defence is heavily dependent upon the prosecution, so it would stand to reason that full disclosure should be made to the defence to strike a balance between the parties. Disclosure usually takes 'the form of a bundle of witness statements', and evidence that has not been disclosed before trial may not be regarded as admissible at trial. ${ }^{48}$ However, it is obvious from the provision that a prosecutor has no obligation to disclose to the defence any neutral material or material damaging to the defendant. What is more, if a prosecutor wishes to withhold sensitive material on the grounds of a risk to public interest, the duty of disclosure would become an issue for the court, which must rule how to balance public interest considerations and the interests of open justice and fair trial. ${ }^{49}$ In cases where the sensitive material might undermine the prosecution case or assist the accused's case, the standpoint of the English and the Strasbourg case law is that 'the entitlement to disclosure of relevant evidence is not an absolute right [and] it may be necessary to withhold certain evidence from the defence so as to preserve the fundamental rights of another individual or to safeguard an important public interest ${ }^{50}$ provided that the limitation on the rights of the accused is sufficiently compensated, such as by appointing special counsel..$^{51}$ Taking an excessively adversarial attitude or having a tendency not to help the defence has been somewhat censured by case law, but it can be said that there are still systemic disclosure issues across the criminal justice system in England, ${ }^{52}$ and as the chief constable of Surrey police has recently stated, there is

47 CPIA 1996, s. 3(1).

48 Andrew Ashworth, Mike Redmayne, The Criminal Process (OUP 2010) 269.

49 Ian Dennis, The Law of Evidence (6th edn, Sweet \& Maxwell 2017) 395.

50 Rowe and Davis $v$ United Kingdom (2000) 30 E.H.R.R. 1 [61]; see also R v H [2004] UKHL 3.

51 Andrew Ashworth, Mike Redmayne, The Criminal Process (OUP 2010) 269.

52 Patrick Cowling, 'Hundreds of cases dropped over evidence disclosure failings' (2018) http://www.bbc. co.uk/news/uk-42795058 accessed 18 April 2018. 
a 'cultural problem with disclosure' that needs to be addressed. ${ }^{53}$ It shows in turn that with respect to rules of disclosure there are still strong adversarial elements that are observable in the English trial culture on the part of the participants although the system has adopted 'the golden rule of full disclosure' ${ }^{54}$

\section{Approaches to Evidence: Admissibility of Evidence vs. Illegal Evidence}

Most of the English law of evidence concentrates on the admissibility of certain types of evidence to seek control over what the tribunal of fact is to access, in other words, inclusionary and exclusionary rules of evidence are the main legal issues that need to be resolved. The primary rationale for the exclusion of evidence stems from the goal of the bifurcated procedure that the tribunal of fact as an amateur adjudicating body should be shielded from certain information, gathered either lawfully or unlawfully, 'which may have an unwanted effect on their reasoning' ${ }^{55}$ It requires that if the judge decides to exclude the evidence, it will not be known to the jury. The idea of admissibility in this context has a different connotation from the evidentiary rule that prohibits 'the use of evidence, but that does not at the same time necessarily prohibit its presentation to the fact-finders' ${ }^{56}$ In the Turkish idea of exclusionary rules, contested evidence is not something that needs to be removed from the dossier after it has been determined as "unlawful",57 rather, it is what should be received and put in the dossier by the trial judge irrespective of impropriety in gathering. ${ }^{58}$ The issue for the judge in this regard is "whether the evidence may be used to reach a verdict rather than a question of exclusion in the common law sense'. ${ }^{59}$ In this sense, the current inquisitorial paradigm in the Turkish criminal trial dictates, in practice,

53 Matthew Weaver, Jamie Grierson, 'Police chief admits 'cultural problem' with evidence disclosure' (2018) https://www.theguardian.com/law/2018/jan/24/more-than-900-criminal-cases-collapse-undisclosedevidence-cps-police accessed 18 April 2018.

54 R v H and C [2004] 2 AC 134 (Lord Bingham).

55 Andrea Ryan, Towards a System of European Criminal Justice the Problem of Admissibility of Evidence (Oxon; Routledge 2014) 73.

56 Ibid, 48.

57 In the Turkish legal literature where the term "illegal evidence" is often used, as opposed to English legal conceptualisation (illegally obtained evidence), there is no emphasis on the means of evidence-gathering because there is no exclusionary rule, such as hearsay or character evidence, that makes evidence "illegal" other than the rules regulating the means of evidence-gathering.

58 Meltem Dündar, ‘İngiliz ve Türk Ceza Muhakemesi Hukuklarında Hukuka Aykırı Deliller' (PhD Thesis, İstanbul Üniversitesi 2014) 510.

59 Andrea Ryan, Towards a System of European Criminal Justice the Problem of Admissibility of Evidence (Oxon; Routledge 2014) 157. 
that the possibility of challenging evidence is a sufficient safeguard, and the judge would be 'presumably trained to exclude inappropriate evidence or inferences from his or her consideration' 60 and undertake the task of adjudicating impartially and fully understanding the legal and factual issues. ${ }^{61}$

In English law, evidence adduced by the parties should be relevant to the facts in issue so as to be admissible and presented in the court. The legal definition of relevance was laid down by Lord Simon in DPP $v$ Kilbourne in which it was held that evidence is relevant if "it is logically probative or disprobative of some matter which requires proof'. ${ }^{62}$ The judge would weigh a set of factors to determine whether the evidence is deemed to be relevant and ought to be admitted in exercising judicial discretion which is rarely subject to the interference of the appellate courts. ${ }^{63}$ The judge must believe that the evidence is sufficiently relevant; however, sufficiently relevant evidence is not enough for admissibility. It should not also be 'excluded by any rule of the law of evidence or by the exercise of judicial discretion' ${ }^{64}$ In this sense, the manner in which evidence is collected and the nature of evidence are of importance to admissibility on the basis that an exclusionary rule or the exercise of discretion might be a basis for exclusion. Where an exclusionary rule applies, the trial judge has an obligation to exclude evidence, whereas where a discretion is relied upon, the judge is not obliged to do so. ${ }^{65}$ For example, if a confession has been gathered by physical violence and threats, or as a result of something said or done likely to render a confession unreliable, the confession must be excluded. ${ }^{66}$ On the other hand, not all evidence that has been obtained improperly automatically leads to exclusion; it is subject to the discretion of judge who has a duty to ensure a fair trial. ${ }^{67}$

60 Ibid, 22

61 There is some controversy among Turkish legal scholars regarding whether the exclusion of evidence from the dossier would be a better solution to avoid the effects of improperly obtained evidence on the trial judge in reaching a verdict. While some authors are in favour of the view that evidence should be excluded from the dossier in any way, others suggest that rather than removing evidence from the dossier, putting evidence in an envelope in the dossier in such a way that the judge cannot see might also help eliminating the negative effects of unlawfully gathered evidence on the judge. Within the confines of this article, I will not be able to discuss the issue in greater depth. See for a more detailed debate: Mehmet Gödekli, 'Türk Ceza Muhakemesinde Maddi Gerçeğe Ulaşmanin Ön Koşulu Olarak Hukuka Aykiri Delillerin Değerlendirilmesi Yasaği’ in AUHFD (2016) 65/4 1815, 1908-1911.

62 [1973] AC 729, [756].

63 Claire McGourlay, Doak Jonathan, Evidence in Context (4th edn, Oxon: Routledge 2015) 8.

64 Adrian Keane, Paul McKeown, The Modern Law of Evidence (Oxford; OUP, 2014) 28.

65 Nicola Monaghan, Law of Evidence (CUP 2015) 148.

66 PACE Act, s. 76(2)(a), 76(2)(b).

67 Nicola Monaghan, Law of Evidence (CUP 2015) 184. 
As such, legally admissible evidence may not always be used at trial and can also be subject to exclusion on the grounds of the discretionary power of the judge. If admissible evidence has a prejudicial effect on the minds of the jury against the accused which outweighs its true value, the judge should exclude evidence from the jury ${ }^{68}$ This approach has been reinforced by section 78 of the Police and Criminal Evidence Act (PACE) 1984 which provides as follows:

In any proceedings the court may refuse to allow evidence on which the prosecution proposes to rely to be given if it appears to the court that, having regard to all the circumstances, including the circumstances in which the evidence was obtained, the admission of the evidence would have such an adverse effect on the fairness of the proceedings that the court ought not to admit it. ${ }^{69}$

The statutory discretion to exclude evidence that is otherwise admissible, to Dennis, is a "preservation of the common law discretion"70 which examines the prejudicial effect of the evidence on the accused and its probative value.

As has been mentioned above, not all relevant evidence in the Turkish criminal proceedings can be used at trial; there is a blanket prohibition on unlawfully obtained evidence according to the Turkish Constitution and the Turkish Criminal Procedure Code. More precisely, in determining whether the accused is guilty the trial judge cannot rely in any way upon unlawfully obtained evidence. Yet, the constitutional and statutory strictness has not been embraced by the case law of the Court of Appeal (Yargitay), which has made inconsistent decisions regarding unlawful evidence. ${ }^{71}$ The Court seems to have justified its stance by adopting an approach which evaluates the inhibition of evidence as either "absolute" or "relative". ${ }^{72}$ The Court is of the view that if evidence is gathered through unlawful means that infringe the basic human rights of the defendant, it must not be used at trial. To put it differently, if unlawful means used by the police or prosecutor in gathering evidence does not affect the

68 [1966] 1 WLR 9 para. 12.

69 Police and Criminal Evidence Act, section 78.

70 Ian Dennis, The Law of Evidence (6th edn, Sweet \& Maxwell 2017) 95.

71 Cumhur Şahin, "Yargıtay Kararları Işı̆̆ında Hukuka Aykırı Deliller ve Değerlendirilmeleri Sorunu", EÜHFD 1.1. (1997) 87.

72 Cem ŞENOL, 'Ceza Muhakemesi Hukukunda Hukuka Aykırı Delillerin Değerlendirilmesi Yasağı' (PhD Thesis, Marmara University 1995) 308. 
rights of the defendant, it can be adduced at the trial stage. ${ }^{73}$ The Turkish Constitutional Court, however, is more stringent than the Court of Appeal in stipulating that "not considering whether there is a human rights infringement, our criminal justice system has preferred the absolute view in evaluating evidence. None the less, as has been mentioned in doctrine and some rulings of the General Assembly of Criminal Chambers, simple procedural unlawful practices should not be regarded as unlawful means in gathering and evaluating evidence." ${ }^{74}$ In a nutshell, the Turkish legal system, albeit explicit constitutional and statutory norms, does not seem to have met the requirements of the blanket rule upon illegally obtained evidence. ${ }^{75}$

Confession evidence is one of the key factors that may have an impact upon the outcome of the trial both in England and Turkey; so improprieties in the manner in which the accused has been interrogated may be grounds for the "exclusion" of evidence in England, and for rendering confession evidence "unlawful" in Turkey. ${ }^{76}$ Unlike confession evidence in Turkey, which is subject to mandatory corroboration requirements, ${ }^{77}$ it is legally possible to convict defendants solely on the basis of their confession in the English common law, although 'in practice there have been sufficient examples to caution courts against the ready acceptance of confessional evidence alone'. ${ }^{78}$ The statutory framework in England introduces a legal test for a confession made by the accused to be admissible. Section 76(2) of PACE provides that if the confession has been obtained by oppression of the person who made it; or

73 Yargitay General Assembly of Criminal Chambers, 10.12.2013, F.N. 2013/10-483 D.N. 2013/599.

74 Turkish Constitutional Court, 2011/1, D.C. 2012/1, (19.12.2012).

75 Various reasons can be evoked for the somewhat failure of the Turkish legal system in applying the law in relation to illegal evidence, but the most remarkable of which, in the view of this author, is the irreconcilability between "searching for the truth as the main goal of the criminal process" and "following strict procedural rules in any way".

76 Veli Özer Özbek, Ceza Muhakemesi Hukuku (Seçkin Yayınları, Ankara, 2006) 673-674; J. Doak, C. McGourlay, Evidence in Context (Oxon: Routledge, 4th Ed. 2015) 202.

77 The mandatory corroboration requirement in Turkey is a requirement imposed by case-law, the Turkish Criminal Procedure Code does not state explicitly whether the statements taken by the accused or suspect can be used as evidence at trial. See the relevant article of the Turkish Criminal Procedure Code, entitled "Procedures forbidden during the interview and interrogation": Article 148 - (1) The submission s of the suspect or accused shall be stemming from his own free will. Any bodily or mental intervention that would impair the free will, such as misconduct, torture, administering medicines or drugs, exhausting, falsification, physical coercion or threatening, using certain equipment, is forbidden. (2) Any advantage that would be against the law shall not be promised. (3) Submission is obtained through the forbidden procedures shall not be used as evidence, even if the individual had consented. (4) Submissions obtained by the police, without the defense counsel being present, shall not be used as a basis for the judgment, unless this submission had been verified by the suspect or the accused in front of the judge or the court. (5) In cases where there is a need for a subsequent interview of the suspect in relation with the same event, this interaction shall be conducted only by the public prosecutor.

78 Claire McGourlay, Doak Jonathan, Evidence in Context (4th edn, Oxon: Routledge 2015) 202. 
in consequence of anything said or done which renders the confession unreliable, the confession must be excluded. ${ }^{79}$ After the defence adduces some prima facie evidence to suggest that the confession is obtained by the prescribed methods, the onus would lie on the prosecution to prove beyond reasonable doubt that the confession was not obtained in breach of the legislation. ${ }^{80}$ Similar to the provision of the PACE Act regarding confessional evidence, the Turkish Criminal Procedure Code stipulates that the confession must depend on the "free will" of the suspect, ${ }^{81}$ and statements obtained through any physical or psychological force in police interrogation cannot be used as evidence in reaching a verdict. ${ }^{82}$ Further, a failure of the interrogator to caution the accused in relation to the rights of him or her before an interview takes place, would also make the confession unlawful. ${ }^{83}$ If the accused is improperly denied access to a legal counsel during police questioning, according to the blanket rule in the Turkish Criminal Procedure Code, statements cannot not be used as evidence of guilt. ${ }^{84}$ This was reinforced by the EctHR case, Salduz v. Turkey in which it was held that because the absence of a lawyer during police interrogation had irretrievably affected the accused's defence rights, the evidence against the accused cannot be adduced at trial. ${ }^{85}$ Though the English common law would not see the absence of legal counsel by itself as the sole ground on which the evidence can be excluded ${ }^{86}$ the UK Supreme Court has made the current law in line with socalled "Salduz reforms" by stating that there is "no room for any escape from the Salduz ruling." $"{ }^{\circ 7}$

Unlike the Turkish criminal trial which makes these types of evidence adducible at trial, bad character and hearsay evidence have been traditionally inadmissible in English criminal proceedings on grounds for the former that it would be irrelevant,

79 PACE Act, s. 76(2).

80 Claire McGourlay, Doak Jonathan, Evidence in Context (4th edn, Oxon: Routledge 2015) 202.

81 It should be emphasised that in Turkish criminal proceedings, the term "suspect" is used for a person who is suspected of having committed a crime, and taking statements from the suspect by the police or prosecutor is called "questioning". The term "accused", on the other hand, is used for a person against whom one or more counts in an indictment have been confirmed. If interviewing the "accused" takes place in front of a judge, it is called "interrogation".

82 Ceza Muhakemesi Kanunu 2004, Art.148.

83 Ibid.

84 Ibid.

85 Salduz v Turkey [2008] ECHR 36391/02 [Grand Chamber] (27 November 2008).

86 Claire McGourlay, Doak Jonathan, Evidence in Context (4th edn, Oxon: Routledge 2015) 223; see also a relevant ruling (1991) 92 Cr App R 228.

87 Cadder v HM Advocate [2010] UKSC 43 (26 October 2010) [50]. 
and for the latter that it would undermine basic tenets of the adversarial system which places a high value on oral evidence given on oath before a jury. ${ }^{88}$ However, it has been increasingly accepted by the courts and legislature that these types of evidence in certain circumstances should be made known to the trier of fact. For example, evidence of bad character will be admissible if it falls under one of the seven 'gateways' mentioned in the statutory provision. ${ }^{89}$ Similarly, the rule against hearsay has four exceptions according to section 114(1) of the Criminal Justice Act 2003. Accordingly, it can be claimed that with the recent reforms, the linchpins of the pure adversarial system in England have been weakened.

Lastly, expert evidence in both jurisdictions would also present interesting insights into how legal traditions have retained, if not completely, their distinctive characteristics. It is true for both countries that material issues that are to be resolved by experts in criminal trial should fall outside the ordinary knowledge or understanding of the court. The difference is that in Turkish criminal trials, expert evidence is not adduced by the parties as in the English criminal trial; it is an impartial judge who decides to gather expert evidence. ${ }^{90}$ Moreover, experts in Turkey are determined by a state institution which oversees standards and maintains a register of experts from all disciplines. ${ }^{91}$ In accord with the inquisitorial paradigm that prioritises truth-finding, impartially gathered expert evidence would consitute the key element of all facts in a particular case before reaching a verdict. Unlike Turkish fellows, experts in England are not determined by a state body that sets out necessary qualifications, and the competency of experts has been one of the points of contention because a number of high-profile miscarriages of justice have occured in the past. ${ }^{92}$ In sum, while the gathering of expert evidence in the Turkish criminal trial is designed to reach the truth with a governing body that deals with the quality of experts, the English adversarial trial seems not close to a regime that regulates expert accreditation.

88 Ibid, 285, 344.

89 Criminal Justice Act 2003, section 101.

90 Expert evidence prepared by an expert who is assigned by the parties with the purpose of receiving special or technical knowledge is called in Turkish criminal proceedings as "uzman mütalaası", which is a different term used for the evidence of the court expert. Although neither type of evidence is prioritised by the trial judge in reaching verdict, the problem for "uzman mütalaası" is the difficulty of determining scientific value of the evidence in question.

91 Handan Yokus Sevuk, 'Ceza Muhakemesi Hukukunda Bilirkisilik' in IUHFM C. LXIV (2006) 49, 59.

92 Claire McGourlay, Doak Jonathan, Evidence in Context (4th edn, Oxon: Routledge 2015) 406. 


\section{Concluding Remarks}

The goals and distinctive features of the trial in the two countries appear to have shaped the fundamental aspects of the law of evidence and the approach of the participants to evidence and proof. However, commitments to inquisitorial or adversarial models are not strict given the reforms of recent decades which took place in both countries. For example, although the aim of the Turkish criminal trial is to reveal the truth, the blanket prohibition of the use of unlawfully obtained evidence at trial makes it more adversarial. In a similar vein, although the assumption in an inquisitorial trial requires full disclosure of evidence at the pre-trial phase, the secrecy of the investigation in Turkey is seen as a reason for non-disclosure. Similarly, the golden rule in England is full disclosure of evidence, although a traditional contest model is not structured in a way that obliges parties to hand over all relevant material. What is common in both jurisdictions is the endeavour to move away from a pure particular model of trial towards a human rights-based process with the difficulty of giving up the habits of the traditional criminal trial. For instance, the overly contest-like nature of the trial and the mindset of the participants in England are still conducive to not putting all the cards on the table before trial, or the Turkish trial, in some respects, cannot be seen far from the truth finding aspect of the inquisitorial system given that illegally obtained evidence is not removed from the dossier. All things considered, the labels "adversarial" and "inquisitorial" cannot be used today to show general character and structure of criminal trial models. They can only be used to help us begin to understand the different features that exist traditionally in different systems, or at best they can be used today to grasp the effects of tradition on the mentality of parties during the trial.

\section{Bibliography}

Ashworth A, Redmayne M, The Criminal Process: An Evaluative Study (OUP 2010).

Bıçak V, 'A Comparative Study of The Problem of The Admissibility of Improperly Obtained Evidence' (PhD Thesis, University of Nottingham 1995).

Case of Garcia Alva V. Germany [2001] Lietzow v. Germany, Application no. 23541/94 (Lietzow v. Germany) Ceza Muhakemesi Kanunu 2004.

Constitution of The Republic of Turkey 1982.

Damaska M, 'Evidentiary "Barriers" to Conviction and Two Models of Criminal Procedure: A Comparative Study’ in U. Pa. L. Rev. (1973) 121506.

Damaska M, 'Structures of Authority and Comparative Criminal Procedure' 84 Yale Law Journal (1974-75) 480 Damaska M, Evidence Law Adrift (Yale University Press 1997).

Damaska M, The Faces of Justice and State Authority: A Comparative Approach to the Legal Process (Yale University Press 1986). 
Dennis I, The Law of Evidence ( $6^{\text {th }}$ edn, Sweet \& Maxwell 2017).

Doak J, McGourlay C, Evidence in Context (4th edn, Oxon: Routledge 2015).

Dündar M, 'İngiliz Ve Türk Ceza Muhakemesi Hukuklarinda Hukuka Aykiri Deliller' (PhD Thesis, İstanbul Üniversitesi 2014).

Gödekli M, ‘Türk Ceza Muhakemesinde Maddi Gerçeğe Ulaşmanin Ön Koşulu Olarak Hukuka Aykiri Delillerin Değerlendirilmesi Yasaği’ 65(4) AUHFD (2016) 1815.

Goldstein A, 'Reflections on Two Models: Inquisitorial Themes in American Criminal Procedure' 26(5) Stan. L. Rev. (1973-74) 1009.

Jackson J, 'Taking Comparative Evidence Seriously' in P. Roberts and M. Redmayne (Eds.) Innovations in Evidence and Proof: Integrating Theory, Research and Teaching (Hart 2007).

Jackson J, 'The Effect of Human Rights on Criminal Evidentiary Processes: Towards Convergence, Divergence or Realignment?’ 68 (5) Modern Law Review (2005) 737.

Jackson J, Doran S, 'Two Models of Proof' in Judge without Jury: Diplock Trials in the Adversary System (Clarendon 1995).

Keane A, McKeown P, The Modern Law of Evidence (OUP 2014).

King M, 'Security, Scale, Form and Function: The Search for Truth and the Exclusion of Evidence in Adversarial and Inquisitorial Justice Systems’ 12 Int'1 Legal Persp. (2001-2) 185.

Landsman S, The Adversary System, a Description and Defence (Washington: The American Enterprise Institute, 1984).

Langer M, 'Models of the Criminal Process' in Markus D Dubber, Tatjana Hörnle(Eds.) The Oxford Handbook of Criminal Law (OUP 2014).

Mireille Delmas-Marty M, Spencer J R (Eds.) European Criminal Procedures (CUP 2002).

Monaghan N, Law of Evidence (CUP 2015).

Okuyucu-Ergün G, ‘Sorușturmanin Gizliliği’ 59(2) AUHFD (2010) 243.

Özbek V O, Ceza Muhakemesi Hukuku (Seçkin Yayınları, Ankara 2006).

Öztunç O, 'Ceza Muhakemesinde Hukuka Aykiri Deliller' (PhD Thesis, Marmara Üniversitesi 2010).

Öztürk B, Yeni Yargıtay Kararları Işı̆̆ında Delil Yasakları (AÜSBF İnsan Hakları Merkezi Yayınları, Ankara 1995).

P. Roberts, 'Faces of justice adrift? Damaska's Comparative Method and the Future of Common Law Evidence' in: J. JACKSON, M. Langer, P. Tillers (Eds.) Crime, Procedure and Evidence in a Comparative and International Context: Essays in Honour of Professor Mirjan Damaska (Hart 2008).

Patrick Cowling, 'Hundreds of cases dropped over evidence disclosure failings' (2018) http://www.bbc.co.uk/ news/uk-42795058 accessed 18 April 2018.

Police and Criminal Evidence Act 1984.

R v H [2004] UKHL 3.

Rowe and Davis v United Kingdom (2000) 30 E.H.R.R.

Ryan A, Towards a System of European Criminal Justice the Problem of Admissibility of Evidence (Oxon; Routledge, 2014).

Sevuk H Y, ‘Ceza Muhakemesi Hukukunda Bilirkisilik’ LXIV IUHFM C. (2006) 49.

Sklansky D, ‘Anti-Inquisitorialism’ (2009) 112(6) Harv. L. Rev. (2009) 1634.

Soyaslan D, 'Hukuka Aykırı Deliller' 7(3-4) AUEHFD (2003) 1.

Spencer J R, 'Adversarial vs inquisitorial systems: is there still such a difference?' 20(5) the International Journal of Human Rights (2016) 601.

The Criminal Procedure Rules, The Criminal Practice Directions October 2015 edition. 
Treasury Minutes on the Fifteenth, Twentieth to Twenty-second and Twenty-fourth Reports from the Committee of Public Accounts 2004-2005, CM6667.

Ünver Y, Hakeri H, Ceza Muhakemesi Hukuku (Ankara: Adalet Yayınları 2012).

Vogler R, A World View of Criminal Justice (Aldershot: Ashgate 2005).

Yargitay Case, E. 2014/195, K. 2015/116, 23.12.2015.

Weaver M, Grierson J, 'Police chief admits ‘cultural problem' with evidence disclosure' (2018, the Guardian) https://www.theguardian.com/law/2018/jan/24/more-than-900-criminal-cases-collapse-undisclosedevidence-cps-police accessed 18 April 2018. 